INTERNATIONAL JOURNAL OF MULTIDISCIPLINARY RESEARCH AND ANALySis

ISSN(print): 2643-9840, ISSN(online): 2643-9875

Volume 05 Issue 02 February 2022

DOI: 10.47191/ijmra/v5-i2-11, Impact Factor: 6.072

Page No.- $308-318$

\title{
An Integrated Model to Tackle the Non-Appropriation of Agricultural Storage Facilities by Project Target Communities in
}

\section{Senegal}

\author{
Souleymane Dia ${ }^{1}$, Alpha Cisse ${ }^{2,3}$, Mbacke Sembene ${ }^{3}$, Rosnert Ludovic Alissoutin ${ }^{4,5}$ \\ ${ }^{1}$ National Agency for youth Insertion and Agricultural Development (ANIDA), , Tambacounda, Senegal \\ ${ }^{2}$ University Alioune Diop of Bambey, National College of Agricultural and Rural Studies (ISFAR), Crop Production Department, MB \\ 54 Bambey, Senegal \\ ${ }^{3}$ University Cheikh Anta DIOP, Faculty of Sciences and Technology, Département of Plant and Animal Biology, Laboratory of \\ Botany and Biodiversity, Genetics, Entomology and Population management Research Group, MB 5005 Dakar, Senegal \\ ${ }^{4}$ Higher Institute of Entrepreneurship and Management (ISEG), Dakar, Senegal \\ ${ }^{5}$ University Gaston Berger, Saint Louis, Senegal
}

\begin{abstract}
The storage facilities of agricultural projects are not fully used by Senegalese producers. To appraise the nonappropriation, we used a mixed approach. First, we interviewed fifteen (15) officials and eight (08) farmers' representatives. We identified five (05) clusters of factors: the low production, the project shortcomings, the unfavorable environment, the sociocultural realities and the storage facility construction. Secondly, we surveyed a sample of seventy five (75) farmers. We found that stores are mainly used for inputs (48\%) and cereals (22.7\%). Low usage over time (below 6 months for $81.4 \%$ of farmers) and space (below $1 / 3$ of the facility for $60 \%$ of farmers) derived from the low agricultural production (36\%) and cultural habits (28\%). We recommend an integrated PASTE solutions (Partnership, Administrative, Socio-cultural, Technical and Economic) model to overcome the non-appropriation of the storage facilities.
\end{abstract}

KEYWORDS: non-appropriation - storage - project - integrated model -Senegal

\section{INTRODUCTION}

Developing countries receive considerable amounts of money, usually in the form of development projects from development partners. The World Bank, for example, had financed 568 projects/programs worth US\$56.19 billion in 47 African countries as of March 20, 2017 [1]. However, the impacts of these projects on disadvantaged populations remain limited. The desire to make Official Development Assistance (ODA) more effective has been greatly strengthened [2], particularly through the identification of limiting factors:

- Corruption, poor governance, predatory elites and states [3],

- Poor quality public policies [2],

- Exogenous shocks such as the volatility of commodity prices [4].

The rationalization of ODA will impose the adoption of Results-Based Management (RBM) theorized by Peter Drucker in the 1960s (Managing for results in 1964). RBM gives an important place to the evaluation of projects. The evaluation of project impacts focuses on several criteria, including sustainability, one of the major pillars of which is ownership, which is measured by a feeling of ownership of the innovation and capacities developed by the beneficiaries [5]. However, the beneficiary communities do not generally take ownership of the infrastructure built for them. This lack of ownership is linked to various reasons. The wait-and-see attitude of certain populations who make no effort to develop and monitor development action plans [6] considerably reduces the chances of ownership. Project governance, cumbersome procedures, corruption, activity monitoring and beneficiary support systems can prevent ownership by the populations [7]. Community-based producer organizations (PO) are often limited to seizing opportunities that arise from projects or other programs launched by the state and development partners [8]. 


\section{An Integrated Model to Tackle the Non-Appropriation of Agricultural Storage Facilities by Project Target Communities in Senegal}

Non-appropriation is very marked for agricultural investment projects in Senegal, where community participation in agricultural projects is often driven by immediate interests (perdiems, participation in national or international events...). As a result, the motivation to sustain the project's results fades as soon as the project stops providing these benefits. This results in the annihilation of the impacts of these projects, especially the works that end up falling into disuse.

One of the most common structures built by agricultural projects is the warehouse, as the storage of harvested grain is one of the most important segments of the agricultural activity. Indeed, it secures the production, rations and income of producers [9]. In addition, the storage of agricultural products fully participates in the supply of markets in sub-Saharan Africa [10].

Depending on the crop, producers use containers (bag, can, drum) and structures (silos, granaries, stores) especially for grains such as maize [11].The other widespread structures for large quantities of grain are of the aerated type representing $70-80 \%$ of storage facilities in developing countries [12]. For the construction of stores, many producers use alternative materials such as banco [13]. Despite their many storage options, producers very often face post-harvest losses estimated at $14 \%$ globally [14]. To address these constraints, community storage stores are a sustainable alternative. Unfortunately, these infrastructures come up against the lack of confidence of producers in communal storage [15]. This observation raises the question of the explanatory factors for the non-appropriation of storage facilities.

The objective of this study is to contribute to the identification of factors favoring the ownership of the deliverables of agricultural development projects in Senegal.

Specifically, it will aim to:

Identify the expectations of communities that agricultural projects have been able to meet;

$\sim$ Characterize the autonomous agricultural development initiatives of the populations;

$\sim$ Analyze the approaches and practices of exogenous agricultural development initiatives;

$\sim$ Analyze the strategies proposed for the development of agricultural storage infrastructures.

\section{MATERIALS AND METHODS}

The study area covers the region of Kédougou (Senegal). Located at the eastern end of the country at $12^{\circ} 33^{\prime} 28^{\prime \prime} \mathrm{N}$ and $12^{\circ} 10^{\prime} 27^{\prime \prime} \mathrm{W}$, it covers an area of $16,896 \mathrm{Km} 2$, or $8.6 \%$ of the national area.

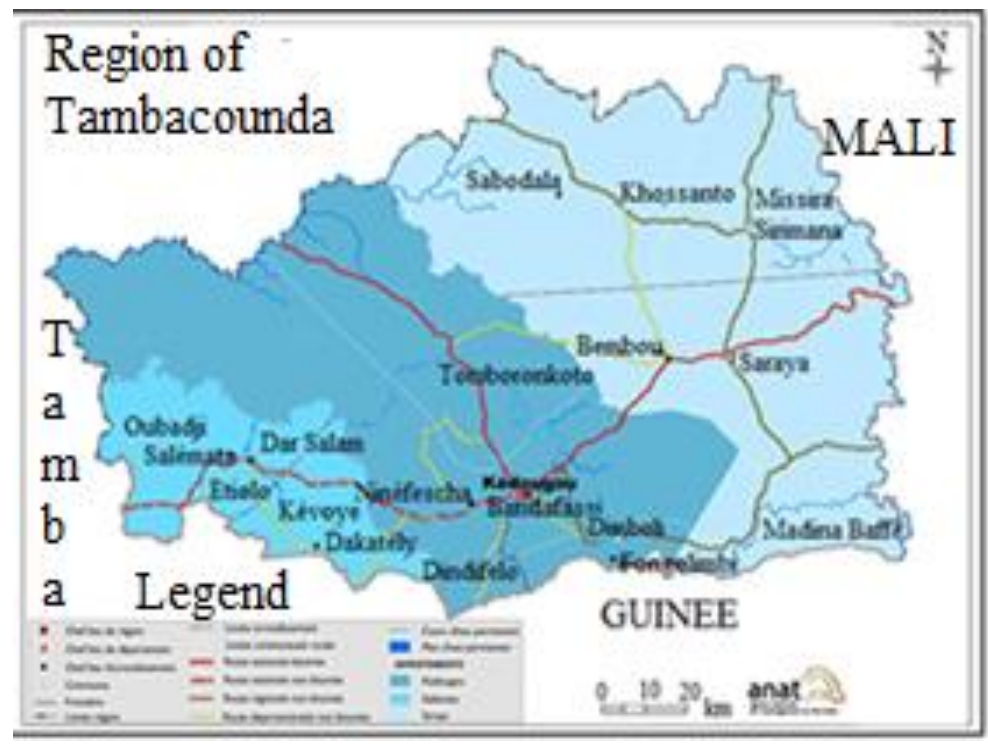

Figure1: Study area

Department of Saraya

Department of Kédougou

Department of Salémata

We were interested in the following information:

- People's expectations 


\section{An Integrated Model to Tackle the Non-Appropriation of Agricultural Storage Facilities by Project Target Communities in Senegal}

- Autonomous development initiatives

- Exogenous development initiatives

- Strategies for developing and appropriating agricultural storage infrastructure

Information was collected from state and institutional actors

- Beneficiary populations

- Administrative and territorial authorities

- Support structures (technical services, projects, NGOs)

A review of the available documentation was carried out in order to better understand the main lines of our theme. Subsequently, the subject of the study was addressed through a mixed approach combining qualitative research (interview guide) and quantitative research (questionnaire).

\section{A. Qualitative Study}

The qualitative study was carried out through semi-structured interviews that allowed for the framing of the exchanges with the resource persons and the targeted communities. The choice of interviewees was guided by their knowledge of the study topic, their level of involvement in the implementation of development policies at the regional level and their experience with agricultural projects. Thus, we exchanged with officials and specialists (administrative services, technical services, communes, NGOs, POs) to better understand the ins and outs of the non-appropriation of project achievements.

Table 1. Interview Participants

\begin{tabular}{|c|c|c|c|c|}
\hline $\begin{array}{l}\text { Interview } \\
\text { type }\end{array}$ & $\begin{array}{l}\text { Date of the } \\
\text { interview }\end{array}$ & Service & Role & Locality \\
\hline Individual & $23 / 11 / 2021$ & DRDR & Director & Kedougou \\
\hline Individual & $26 / 11 / 2021$ & SDDR & Technical Officer & Kedougou \\
\hline Individual & $27 / 11 / 2021$ & SODAGRI & Manager & Kedougou \\
\hline Individual & $30 / 11 / 2021$ & $\begin{array}{l}\text { Department } \\
\text { Council } \\
\end{array}$ & SG & Kedougou \\
\hline $\begin{array}{l}\text { Focus } \\
\text { Group }\end{array}$ & $01 / 12 / 2021$ & $\begin{array}{l}\text { Producers' } \\
\text { Organisation }\end{array}$ & Members (08) & $\begin{array}{l}\text { Tomboronkoto, } \\
\text { Sékoto, Lamé, } \\
\text { Bafoundou, } \\
\text { Temassou }\end{array}$ \\
\hline Individual & $01 / 12 / 2021$ & ANCAR & $\begin{array}{l}\text { Agricultural } \\
\text { advisor }\end{array}$ & Kedougou \\
\hline Individual & $02 / 12 / 2021$ & NGO KEOH & President & Kedougou \\
\hline Individual & $03 / 12 / 2021$ & P2RS & Manager & Kedougou \\
\hline Individual & $04 / 12 / 2021$ & PAPIL & Assistant & Kedougou \\
\hline Individual & $08 / 12 / 2021$ & PADAER-I & Manager & Kedougou \\
\hline Individual & $22 / 12 / 2021$ & $\begin{array}{|ll|}\text { Khossanto City } \\
\text { Hall }\end{array}$ & Mayor & Khossanto \\
\hline Individual & $23 / 12 / 2021$ & $\begin{array}{l}\text { Tomboronkoto } \\
\text { City }\end{array}$ & Mayor & Tomboronkoto \\
\hline Individual & $23 / 12 / 2021$ & $\begin{array}{l}\text { Animal } \\
\text { Production } \\
\end{array}$ & Manager & Kedougou \\
\hline Individual & $24 / 12 / 2021$ & ARD & Director & Kedougou \\
\hline Individual & $07 / 01 / 2022$ & GADEC & Manager & Kedougou \\
\hline Individual & $13 / 01 / 2022$ & CORENA & Coordinator & Tambacounda \\
\hline
\end{tabular}

\section{B. Quantitative Study}




\section{An Integrated Model to Tackle the Non-Appropriation of Agricultural Storage Facilities by Project Target Communities in Senegal}

We conducted a collection followed by an analysis of quantitative data related to the users of the stores, the establishment of these stores, their management, and possible paths for improvement.

We followed the methodology of [13] consisting of first selecting the communes with the Region's technical services. Then, an exploratory study was conducted in the selected communes to target villages within which 5 producers using the stores were randomly selected. In total, 75 producers in 15 villages were approached. The surveys were conducted by a team of three operators during the month of December 2021.

\section{Data collection and analysis}

Due to the adoption of a mixed-methods approach, a variety of tools were used:

An interview guide for the qualitative study

A questionnaire for the quantitative study

Once the data had been collected, we proceeded to process the qualitative data by grouping the information according to the major axes. The quantitative data was processed using MS Excel and SPSS software to visualize and characterize the main trends.

\section{RESULTS}

\section{A. The Integrated Application Model to the Non-appropriation}

We proceeded to classify and prioritize the most important causes. For each of the main causes, root causes were identified.

i) The low level of agricultural production, which makes the use of storage of little relevance. Indeed, agricultural production is characterized by low yields associated with low acreage due to multiple underlying causes

- Poor access of producers to credit, inputs and lowland development

- Inaccessible agricultural equipment (cost, number, suppliers too far from the region)

- Important post-harvest losses linked to biotic and abiotic factors

ii) The physical and socio-economic environment marked by

- the isolation of high production areas, which makes the location of stores unsuitable because they are located in villages on major roads

- a very high level of vulnerability of households to inflation, which is accentuated in the Kédougou region due to gold mining. Thus, many of these households cannot store food because they are food insecure.

iii) Several stakeholders complained that their involvement was more symbolic than functional. Key actors such as local authorities and technical services are only solicited for secondary activities or during ceremonial events (training certificate ceremony, etc.). For the major phases, the project calls on its own resources or contractors not bound by a mandate to perpetuate the results.

iv) The technical failures of the stores making these works unusable

v) The human factor through

- The shortcomings of producers' organizations and

- Traditional storage practices that are not in line with community stores.

These different constraints can be mitigated by the adoption of an integrated model of PASTE solutions (Partnership, Administrative, Socio-cultural, Technical and Economic). 


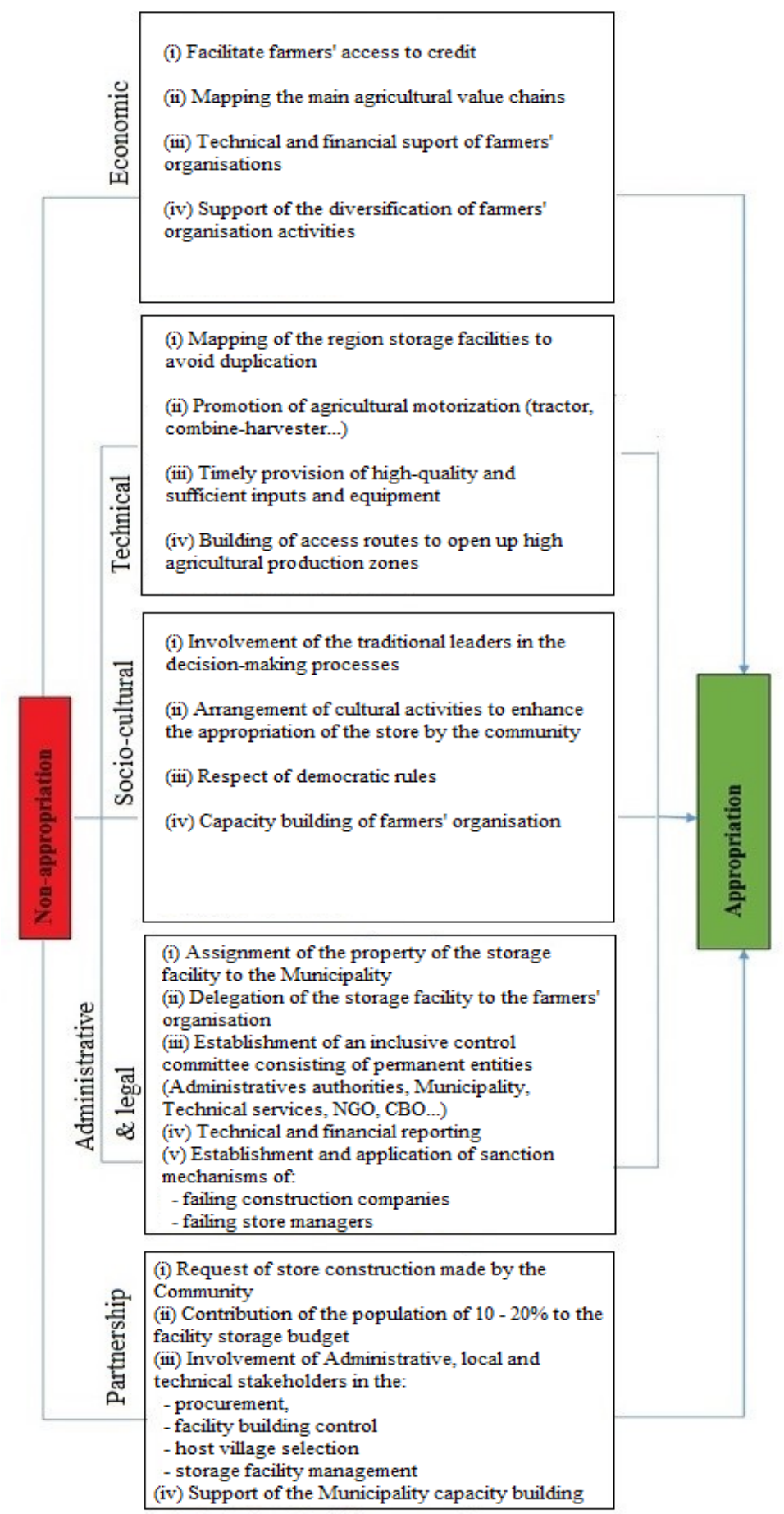

Figure2: Application model of solutions to non-appropriation

\section{B. Surveys}

1) Identification of store users: The users are mainly men with $86.7 \%$. This trend is explained by the distribution of agricultural tasks in rural areas, which assigns certain tasks to men. Producers have a relatively low level of education, with $60 \%$ having completed primary school or having received no education. Nearly a third of producers (34.6\%) have received instruction in a language other than French (13.3\% in local language or Arabic) or in French at an intermediate level (21.3\% in middle or secondary school). The remaining $5.3 \%$ of producers have continued their studies to higher education. The use of the store is the responsibility of married producers who make up almost $100 \%$ (98.7\%) of the sample.

2) Setting up the stores: The location of the store is poorly chosen because it is too far from the polarized villages (26.7\%). For the other producers, the store is either at a reasonable distance from the polarized villages (53.3\%) or in the village (20\%). The capacity of the store is considered sufficient by $52 \%$, while $48 \%$ think the opposite. Less than a third of producers ( $20 \%$ ) think 


\section{An Integrated Model to Tackle the Non-Appropriation of Agricultural Storage Facilities by Project Target Communities in Senegal}

that the stores are well built. The others are circumspect, stating that the quality is average (52\%) or poor (28\%). The setting up of the stores is essentially a local request (76\% come from the population or the POs). The Commune can also initiate the request $(9.3 \%)$. Other possibilities such as project or program interventions may also arise (14.7\%).

3) Warehouse management: The management bodies of the stores are mainly chosen through participatory processes, either through elections (57.3\%) or through informal consultations (33.3\%). The other processes for appointing the management body are marginal with $5.3 \%$ (selection by third parties) or $4 \%$ (no management body).

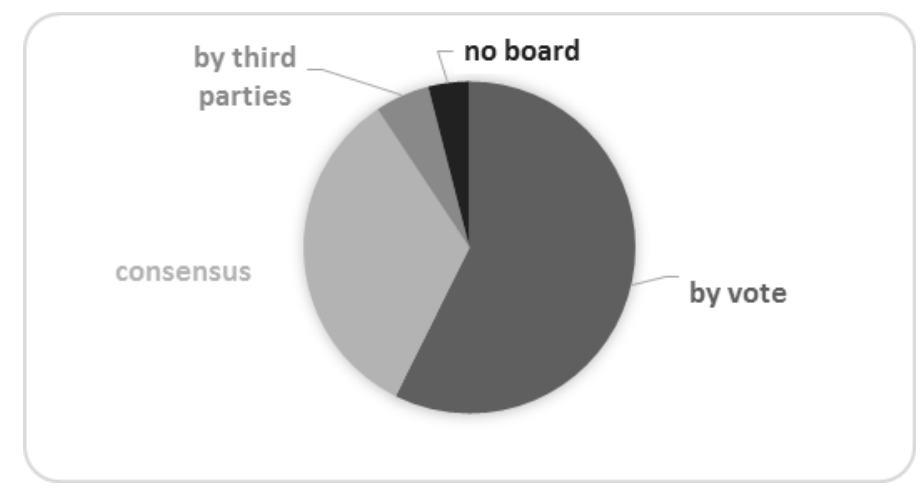

Figure3: Warehouse board selection

Meetings are not held for $41.3 \%$ of stores. A very small proportion of stores, $6.7 \%$, hold meetings on a monthly basis. The majority of stores hold meetings every six months $(32 \%)$ or every year $(20 \%)$.

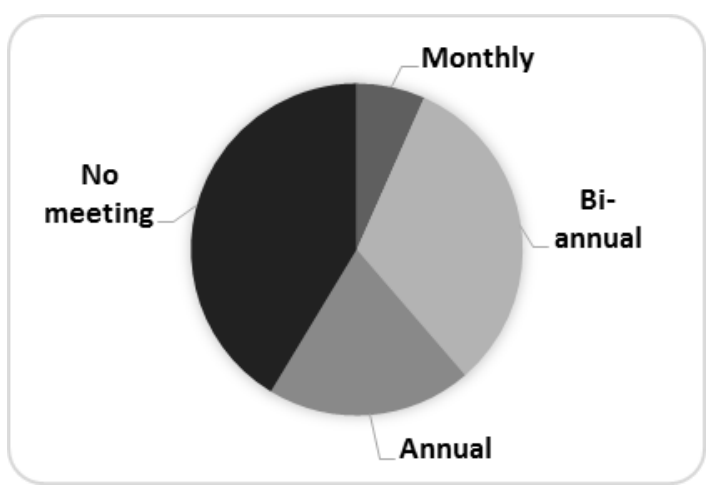

Figure 4: Meeting frequency

The absence of control by the management bodies is the most common trend with $50.7 \%$. When control is exercised, the structure responsible may be the producers' organization (22.7\%), a multi-stakeholder committee (17.3\%), the host commune $(6.7 \%)$ or the project that initiated the establishment of the store $(2.7 \%)$.

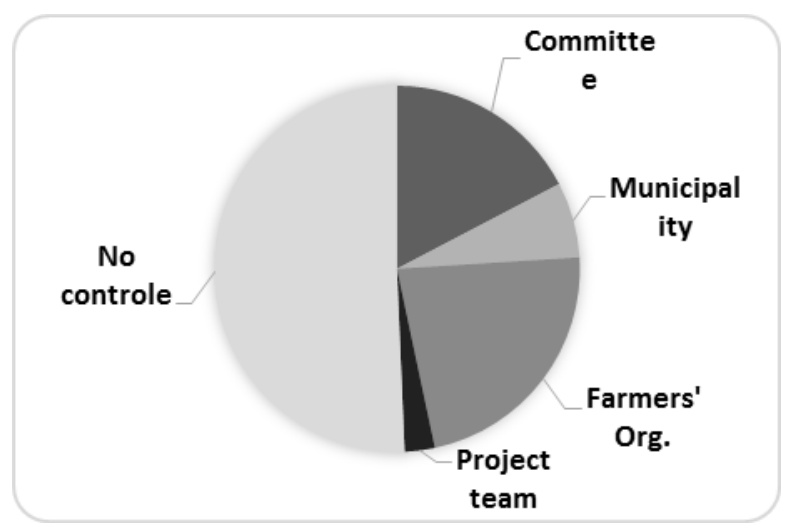

Figure5: Board control 


\section{An Integrated Model to Tackle the Non-Appropriation of Agricultural Storage Facilities by Project Target Communities in Senegal}

Warehouses are mainly used for agricultural inputs subsidized by the state (48\%).

Storage of harvested cereals is also common, at $22.7 \%$. Crops intended for marketing pass through the stores in the case of groundnuts (5.3\%) and other crops (9.3\%). Agricultural materials and the lack of use of the store together account for $6.7 \%$ and $4 \%$ respectively.

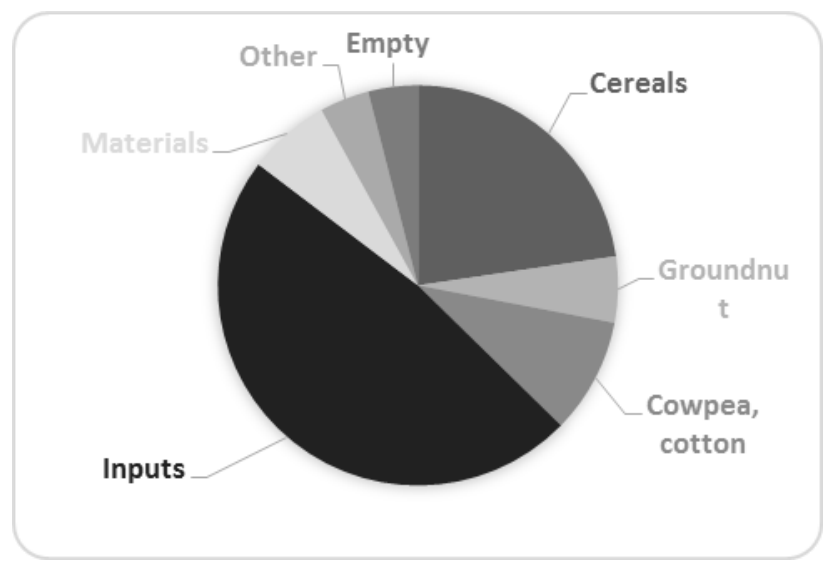

Figure6: Main storage items

The stores seem to be under occupied. Only $40 \%$ of producers believe they are completely full. According to the majority of producers, the stores are only one third (16\%) or half full (44\%).

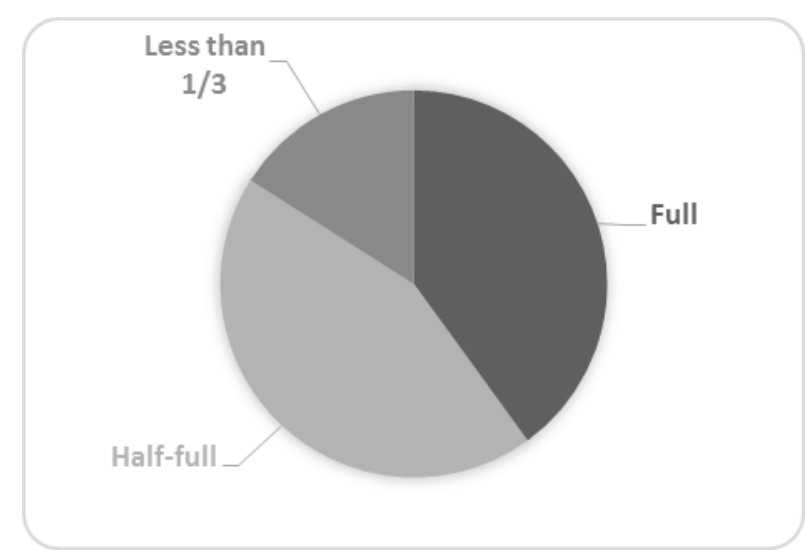

Figure7: Warehouse occupation

The low level of occupancy noted above is accompanied by a short duration of occupancy which is less than three months and between 3 and 6 months according to $30.7 \%$ and $50.7 \%$ of the producers respectively. Only $18.7 \%$ of the producers estimate that this duration exceeds 6 months.

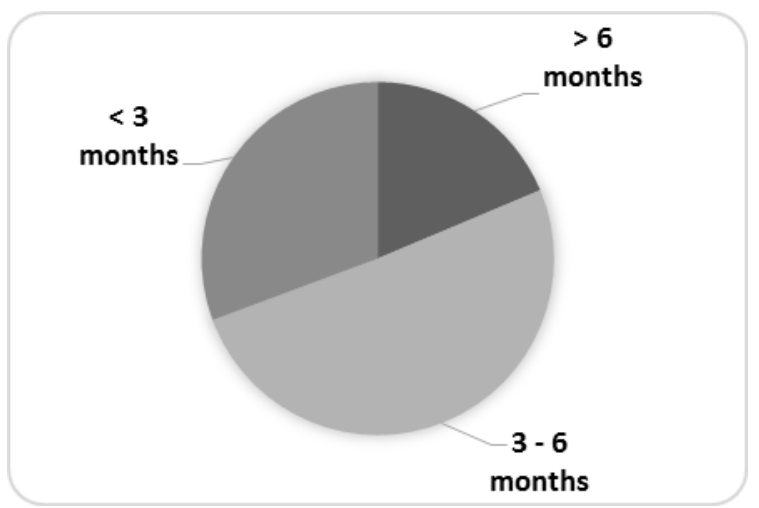

Figure 8: Duration of the warehouse occupation

The stores fulfill a community role of storing inputs for communities or producer organizations. As such, they rarely contribute to income generation (84\%). However, $16 \%$ of producers say that this can happen when they rent the stores. 


\section{An Integrated Model to Tackle the Non-Appropriation of Agricultural Storage Facilities by Project Target Communities in Senegal}

4) Ways to improve the ownership of the stores by the population: According to $57.3 \%$ of producers, the lack of harvesting and post-harvest equipment is the main constraint that hinders agricultural activity. The second major constraint is access to inputs and agricultural credit according to $26.7 \%$ of producers. The other expectations are, in order of priority, bio-aggressors (6.7\%), the unavailability of labor (5.3\%) and storage facilities (4\%)

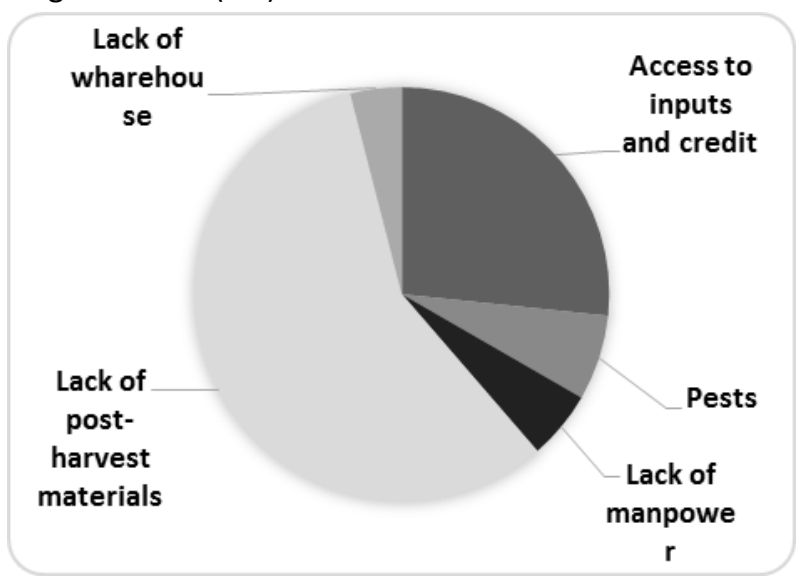

Figure 9: Main agricultural constraints

Nearly one-third of producers (34.7\%) believe that stores are important for procurement. Other producers consider that the most important role of the stores is to secure seeds $(29.3 \%)$ and marketable goods (12\%). Thus, it appears that $76 \%$ of the producers consider the stores to be a crucial part of the agricultural activity. The remaining producers use the stores for nonagricultural activities such as storing subsidized food (18.7\%), renting them out to generate income (2.6\%) or for other purposes (meetings, etc.).

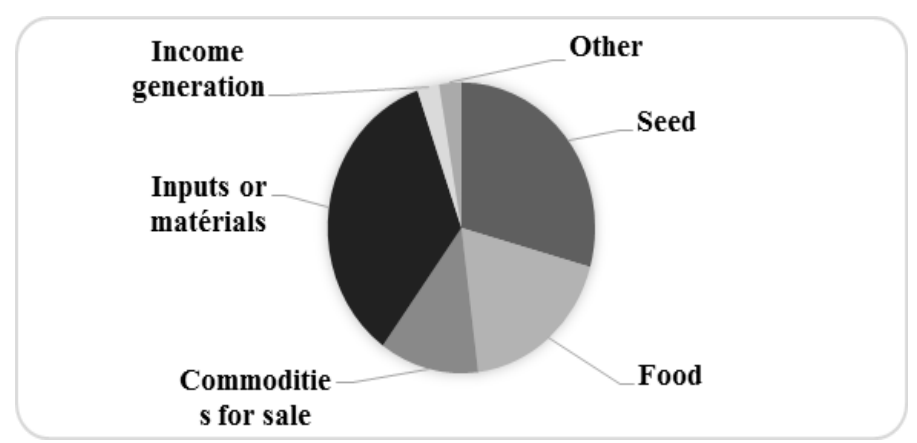

Figure 10: Most important warehouse functions for farmers

The two main reasons for not using the stores are the low level of agricultural production (36\%) and cultural habits of individualized crop storage (28\%). The poor management of these facilities by the store management committees is relatively important (13.3\%). The other reasons for non-use are the non-involvement of the population in the process of setting up the stores $(4 \%)$, the poor quality of the stores $(4 \%)$, the poor selection of beneficiaries $(1.3 \%)$ or other factors more related to the producers or the communities (10.7\%).

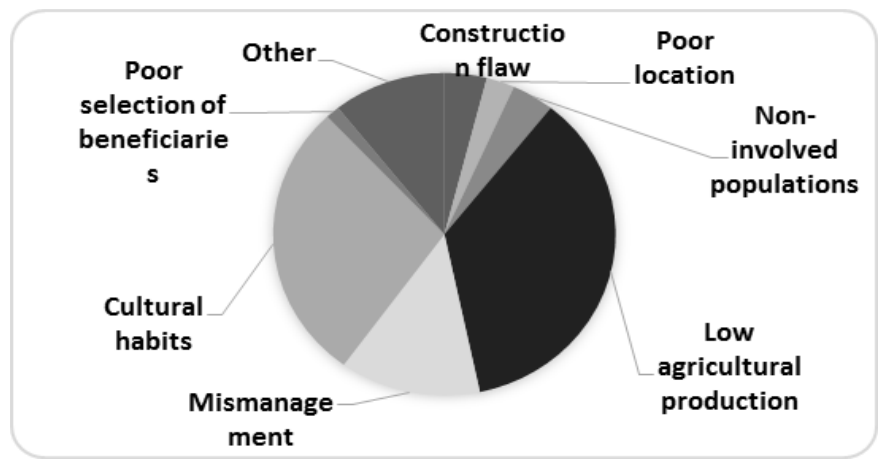

Figure 11: The causes of the warehouse non-utilisation 


\section{An Integrated Model to Tackle the Non-Appropriation of Agricultural Storage Facilities by Project Target Communities in Senegal}

\section{DISCUSSION}

1) Model: Several social models have been applied to agriculture, particularly in the sustainable development of entrepreneurship [16], integrated agricultural risk evaluation [17] or agricultural education [18]. However, there is a need to develop more tools to enhance the appropriation of agricultural project achievements.

2) User profile: The management of inputs and crops seems to have a cultural connotation that places women and those who are not yet married in second place. Women face more constraints in their agricultural activities than men whether it is access to land, access to irrigation water, access to credit and access to agricultural inputs [19]. Thus, women's involvement in the management of community stores is very low, hence the emergence of innovations such as the Greniers Féminins de Soudure (GFS), which are grain stocks exclusively constituted, managed and intended for women [20].

One of the main manifestations of the low level of education of producers, particularly women, is felt through the low level of agricultural productivity [21].

3) Setting up the store: Most producers (73.3\%) liked the location of the stores. This positive trend contrasts with the pronounced skepticism of producers regarding the capacity and quality of the facilities, which they consider to be average to poor at $48 \%$ (capacity) and $80 \%$ (quality) respectively. This opposition between an endogenous need expressed by the populations and an external intervention poorly adapted to local expectations places the cursor of non-appropriation on the inadequacy of the projects' achievements with local realities. Other studies have shown that it is essential to analyze the needs of producers based on their own logic and criteria [22] in order to expect them to appropriate the proposed technologies.

4) Store management: The under-occupation of warehouses by PO members is easily understood by their lack of involvement in the running and management of the warehouses by the leaders (rare meetings, lack of control by management committees, etc.). The warehouses are used, in priority, for the storage of inputs (48\%) and cereals (22.7\%). This trend was also noted by [23], who reports the use of village stores for the storage of paddy rice and husked rice.

Overall, the stores do not generate income (84\%). This may be due to the way the store is acquired, which does not include a financial contribution from the PO. [23] reports the experience of the Foabougou village association, which managed to generate revenue from two of its stores that it built with its own funds. It should be noted that these stores were equipped with post-harvest equipment (scales, threshing machine, huller) that allowed them to meet the additional demands of producers for storage and post-harvest operations.

5) Pathways to improvement: Since the main constraints in agriculture (84\%) are the lack of agricultural equipment and difficulties in accessing credit and inputs, any given store implementation must integrate mechanization and improved access to credit and inputs. In addition, the store must be placed throughout the agricultural activity and respond to the interconnected expectations of producers. The mono-functionality of the stores is a major shortcoming that can considerably affect their level of use. Low agricultural production and cultural habits are two apparently independent but in reality linked factors. In fact, traditional agriculture was mainly intended to satisfy family needs. In addition, the entire production process was thought out and implemented within the concession, and crops were stored exclusively in family granaries. However, increasing production levels through the use of modern equipment, inputs and other technologies can provide sufficient crops for consumption, sale and storage. In other words, raising production levels will create a need for storage that will overcome any cultural reluctance.

\section{CONCLUSIONS}

The State of Senegal and its development partners are working to improve the well-being of the population and their economic development through significant sectoral investments, particularly in agriculture. It is thus common to see agricultural projects intervene in the various agro-ecological zones to strengthen human capital or structurally transform the determinants of the economy of the intervention zones. With this in mind, several storage warehouses have been built at the request of the communities. Paradoxically, these warehouses are little used by the beneficiary communities if they are not simply abandoned. The qualitative and quantitative study of this phenomenon of non-appropriation has made it possible to identify original (project development), operational (non-involvement of key actors) and contextual (low level of performance of the agricultural sector) causes. The systemic analysis of the explanatory factors of the phenomenon has led to the development of an integrated model that would allow for a better appropriation of project achievements by the beneficiary communities. Nevertheless, our study does not pretend to solve the major problem of non-appropriation, given its scope, complexity and tenacity. However, the reasoned and adapted implementation of the transformation framework of the proposed PASTE solutions could play an important role in its mitigation or even its progressive dissipation. 


\section{An Integrated Model to Tackle the Non-Appropriation of Agricultural Storage Facilities by Project Target Communities in Senegal}

\section{ACKNOWLEDGMENT}

The authors would like to thank MM Abdou DIOUF, Boubacar DIOUF, Abdoul BA and Seydou KANE for their valuable advice.

\section{REFERENCES}

1) Bossou, L. 2017. Étude exploratoire des facteurs d'appropriation des résultats des projets et programmes de développement par les bénéficiaires : cas des projets financés par le Fond International de Développement Agricole (FIDA) au Bénin, Master dissertation, University of Quebec at Chicoutimi, Quebec, $147 \mathrm{p}$.

2) Jacquet, P. 2006. Revisiter I'aide publique au développement. Economie internationale, 4(108): 139-152 p.

3) Easterly, W., Levine, R., Roodman, D. 2003. New data, new doubts: A comment on Burnside and Dollar's “Aid, Policies, and Growth" (2000), National Bureau of Economic Research, NBER Working Paper 9846: 774-780 p.

4) Guillaumont, P., and Chauvet, L. 2001. Aid and performance: a reassessment. Journal of Development studies, 37(6): 66-92.

5) Ouédraogo, H. B. 1992. L'appropriation des projets de développement: le cas des Micro-réalisations au Burkina Faso. Actes et instruments de la recherche en développement régional, $N^{\circ} 9: 1-133 p$.

6) Tchagbèlè, A. 2019. Faible appropriation des projets par les communautés partenaires de l'ONG Plan International Togo (PIT), Unité de programme de Sokodé au Togo. International Journal of Innovation and Applied Studies, 25(2): 594$604 p$.

7) Okereke, O. C. 2017. Causes of failure and abandonment of projects and project deliverables in Africa. PM World Journal, 6(1): 1-16 p.

8) de Miranda, R. P., Thiam, A. \& Klug, I. 2017. Le ciblage des agriculteurs dans les programmes d'approvisionnement institutionnel : le cas du PAA Afrique au Sénégal. Centre International de Politiques pour la Croissance Inclusive (IPC-IG), Brasilia, $26 \mathrm{p}$.

9) Scheepens P., Hoevers R., Arulappan F. X., Pesch G. 2011. Le stockage des produits agricoles tropicaux. Agromisa et CTA, Agrodok Serie $\mathrm{n}^{\circ} 31 . \mathrm{5}^{\mathrm{e}}$ ed, Wageningen, Pays Bas. $84 \mathrm{p}$.

10) Nzossie, E. J. F., Temple, L., and Ndamè, J. P. 2016. Infrastructures de stockage agricole (ISAC) dans la zone soudanosahélienne du Cameroun: conditions de gouvernance d'un bien commun pour la sécurisation alimentaire. Revue d'économie du développement, 24(3) : 107-127 p.

11) Gueye, M. T., Seck, D., Wathelet, J. P., and Lognay, G. 2012. Typologie des systèmes de stockage et de conservation du maïs dans l'est et le sud du Sénégal. BASE, 16(1): 49-58.

12) Kossou, D. K., and Aho, N. 1993. Stockage et conservation des grains alimentaires tropicaux: principes et pratiques. Editions du Flamboyant, Cotonou (Benin), $125 \mathrm{p}$.

13) Cisse, A., Kane, A., DIA, S., and Sembene, M. 2018. Evaluation of groundnut (Arachis hypogaea L.) storage methods and Caryedon serratus (Oliver) pest management in the Senegalese Groundnut Basin (Fatick, Kaolack and Kaffrine). Journal of Entomology and Zoology Studies, 6(2), 3079-3086 p.

14) FAO. 2019. The State of Food and Agriculture 2019: Moving Forward on Food Loss and Waste Reduction. Rome, $203 \mathrm{p}$.

15) Rochat, A., and Guenat, D. 2013. Pertes de grains secs durant le stockage au Nord-Ouest du Bénin. Agriculture + Food Security Network Brief, 4: 1-8p.

16) Ivanchenko, V. 2020. Development of a model of sustainable development of entrepreneurship in Agriculture. Technology audit and production reserves, 6(4), 56.

17) Girdžiūtè, L. 2012. Risks in agriculture and opportunities of their integrated evaluation. Procedia-Social and Behavioral Sciences, 62, 783-790.

18) Croom, D. B. 2008. The Development of the Integrated Three-Component Model of Agricultural Education. Journal of Agricultural education, 49(1)

19) Balana, B. B., Appoh, R. K., Addy, P. S., Ashitei, G., Odonkor, E., and Nimoh, F. 2017. Comment l'accès des femmes aux petits réservoirs d'eau peut-il améliorer les moyens de subsistance des ménages dans le nord du Ghana. Water, Land and Ecosystems Briefing Series, 9, $5 \mathrm{p}$.

20) Ekade, R. S. 2019. Capitalisation des expériences au service du développement rural. Report of CTA, FAO and IICA with the financial support ofFIDA, 32-36 p.

21) Ngouambe, N. 2019. Les vidéos agricoles pour accompagner les populations non scolarisées. CTA Série Capitalisation des expériences. $38-42 \mathrm{p}$. 
An Integrated Model to Tackle the Non-Appropriation of Agricultural Storage Facilities by Project Target Communities in Senegal

22) Hinnou, C. L., Agbotridja, V. D., and Adjovi, R. N. A. 2021. Analyse des besoins en mécanisation agricole basée sur les logiques paysannes dans les pôles de développement agricole du Bénin. International Journal of Biological and Chemical Sciences, 15(2): 536-549 p.

23) Koumaré, M. 2021. Economie sociale et biens communs: cas de l'Association villageoise de Foabougou dans la zone de l'Office du Niger au Mali. Canadian Journal of Nonprofit and Social Economy Research, 12(1): 69 - 81 p.

There is an Open Access article, distributed under the term of the Creative Commons Attribution - Non Commercial 4.0 International (CC BY-NC 4.0)

(https://creativecommons.org/licenses/by-nc/4.0/), which permits remixing, adapting and building upon the work for non-commercial use, provided the original work is properly cited. 